\title{
A Pragmatic Perspective: The Power of Words
}

\author{
Beatrice Diana Burcea \\ “Dr. Ioan Meșotă” National College, Brașov, Romania
}

\begin{abstract}
The theory of speech acts has appealed to many researchers thanks to the connections that can be established between literature and linguistics. The action potential of words institutes a distinct rhetoric meant to emphasize the relationship between words and things. In this research, I pursue several ways of conducting a pragmatic investigation into postmodern poetic texts, emphasizing several aspects of the speech acts theory developed by John Austin and continued critically by John Searle. In the first part of the study, I highlight the authority of the narrative voice, while in the second part I outline the aspect of the correspondence with the facts. The corpus of texts subjected to analysis supports the theoretical approach through its variety and pragmatic complexity.
\end{abstract}

Keywords: speech acts, utterance, illocutionary force, pragmatics

\section{Introduction}

The early 20th century was marked by the changing of perspectives on language. In the context of logical positivism, the theory of speech acts developed by John Langshaw Austin drew the scholars' attention by virtue of the importance it gave language within social reality. This understanding of language as an act served as the foundation of linguistic pragmatics.

In Romanian postmodern poetry, the authority of narrative voice brings into focus complex perlocutionary effects. Correlated with various forms of description, they maintain the ambiguity of the speaking subject's status. The difficult operation of distinguishing between illocutionary and perlocutionary acts, acknowledged as such by Austin (1962, 2005), is not an impediment to decoding the expressive potential of an utterance.

The major constative-performative distinction emphasizes the locutionary versus the illocutionary aspects of the utterance, highlighting the dimension of correspondence with the facts. Austin's research was continued by John Rogers Searle, who set forth the necessary criteria for identifying illocutionary acts. Approaching postmodern poetic texts from the perspective of some of the concepts developed by the two philosophers can shed further light onto the pragmatic insights of the speech acts theory. In the spirit of Austin's theory, I will focus on a few aspects concerning the pragmatic functioning of phemes in postmodern poetry. In the spirit of Searle's theory, I will examine various aspects regarding the fit between words and things. Both theories of speech acts have complex realizations in postmodern poetic texts.

Beatrice Diana Burcea, professor, Romanian Language and Literature Department, “Dr. Ioan Meșotă” National College; Ph.D. student, University of Craiova. 


\section{Perlocutionary Acts: The Authority of the Utterer}

In the pragmatics of the text, illocutionary and perlocutionary speech acts are of major importance. While illocutionary acts are distinguished by a potential effect on the receiver, perlocutionary acts guarantee the effect produced on the receiver. Although fictional discourse is denied a pragmatic intention to act (Austin, 2005; Searle, 1979, 1982), its own pragmatic dimension cannot be ignored. As Iser $(1978,2006)$ emphasizes, the very fact that fictional discourse is "parasitical" is a clear indication that there exist speech acts which generate action. Fictional discourse has specific conventions, which it organizes in a manner of its own. According to Austin, the validity of conventions has a "vertical" structure, while the organization of fictional discourse is "horizontal". Conventions are elevated to the rank of themes. Fictional discourse "depragmatizes the conventions it has selected", so much so that it may be stated that "herein lies its pragmatic function" (Iser, 2006, pp. 156-158).

\section{The Description of the to do Type}

In postmodern poetry, perlocutionary effects can take various forms. In Matei Vișniec's text, The Poem That Reads Itself, perlocutionary acts bring into focus the effects of the poem's annihilation. The enunciation scene circumscribes a representative description ${ }^{1}$ of the to do type. ${ }^{2}$ This type of description is not inconsistent with the ascriptivism that is characteristic of the theory of speech acts. The observations of Philippe Hamon (1981) open the perspective for understanding the descriptive strategies of poetic discourse. Description is the action an "actor" undertakes upon the object that is described. The emphasis is no longer laid on an object's features, but on a set of acts/actions targeted at the described object. The text no longer enumerates the parts of the "ideal" object, but presents the range of gestures through which the components of the object are highlighted (apud Adam \& Petitjean, 2007, p. 54). In the poem under analysis here, the description of the object entails its deconstruction. The paradigm of the object's features is "dramatized" through a "programmed series of actions" (ibidem, p. 55). Invested with self-referential attributes, the poem "reads itself", "it slowly unravels its meanings", "it understands itself", and then gradually disappears into the universe:

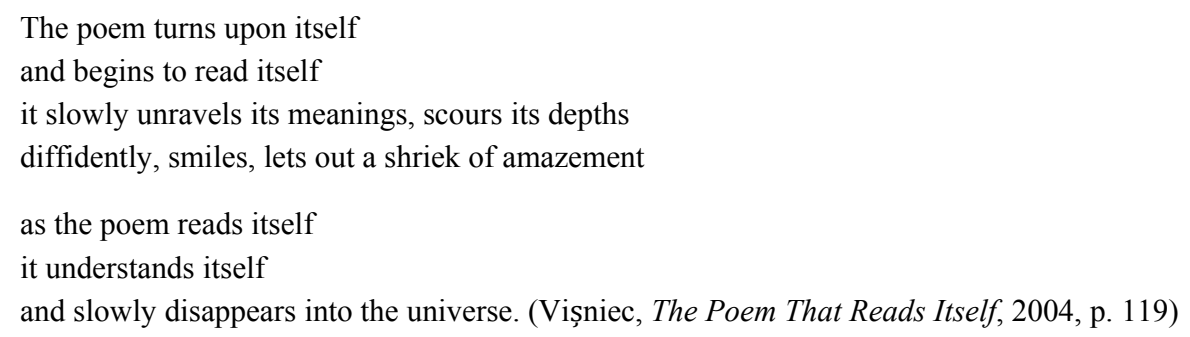

Deconstructed in the unrelenting act of reading, the "actor"/the poem, understood metonymically as an agent of the writerly act, ferociously devours himself/itself. The perlocutionary act maintains the ambiguity of the status of the speaking subject. The self-reflexive gesture annihilates the poem that is alienated as soon as the last word is read ("but the poem breaks into a terrible grin and again / hurls at itself [...] / the poem furiously thrusts

\footnotetext{
${ }^{1}$ In Textul descriptiv (The descriptive text), Jean-Michel Adam and André Petitjean undertake a comprehensive presentation of the threefold classification of description: ornamental, expressive, and representative (2007).

${ }^{2}$ Examining the discursive strategies in the realist novel, Philippe Hamon (1981) highlights the way in which descriptive pauses are motivated. Although the presentation of the description is the "work of the author", the descriptive sequences are sometimes rendered as if they were made by an "actor" (character or narrator), in three different ways: to see, to say, to act (to do) (Hamon apud Adam \& Petitjean, 2007, pp. 49-56).
} 
into / its own innards, swallowing them with a roar"; "the insane poem [...] / reads itself [...] / until the last word falls to its knees and roars in pain"). The conversational simulacrum established between the poem - words - the spirit of the poem - the word relies on the meta-representational strategies of the speaker, who is exposed in the end:

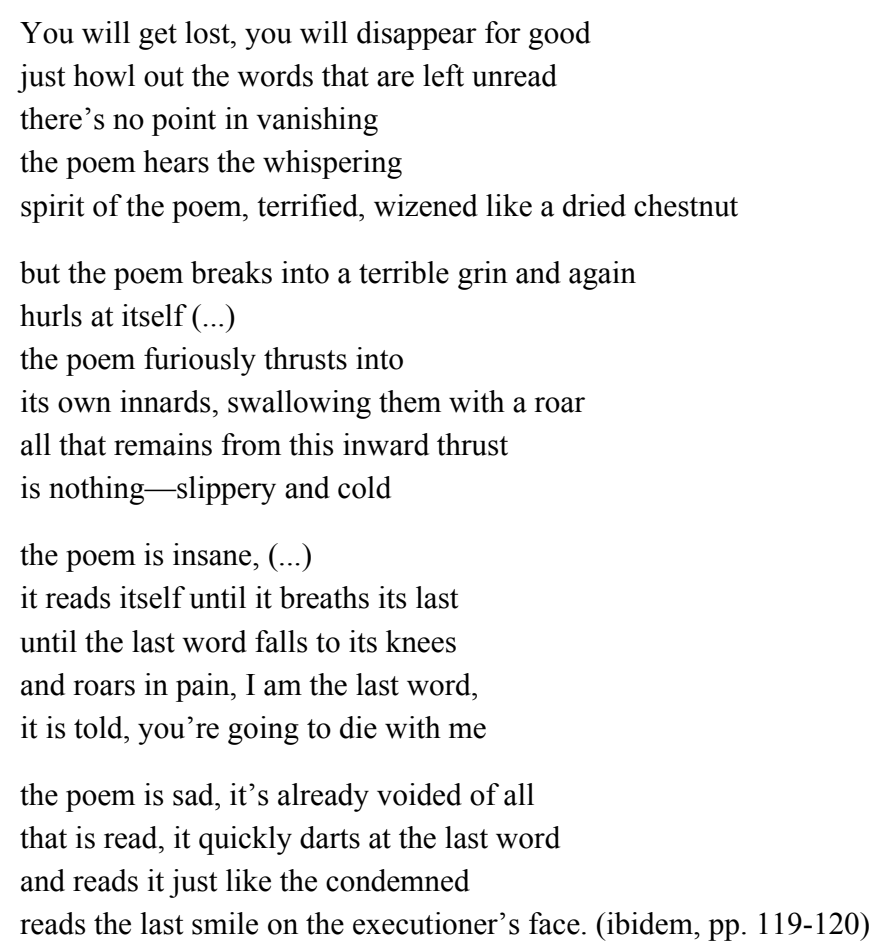

The representative description of the to do type remains anchored in the abandoned writerly code. The all-encompassing white metonymically conveys the spatiality of the text. The devastating perlocutionary effect is reinforced by the enunciatory dissolution. ${ }^{3}$ The presentation of the general framework is reminiscent of the pattern of expressive description (Adam \& Petitjean, 2007, p. 25), which remains the preserve of the speaking I ("mist and water-filled rooftops / are all that's left of the poem"). The enunciation scene ends irrevocably in a cumulative anaphora:

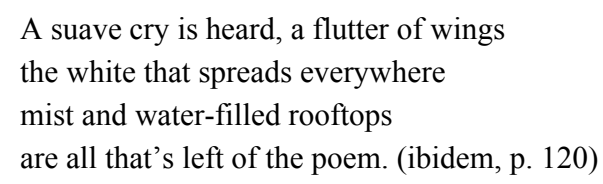

\section{Illocutionary Versus Perlocutionary}

John Austin recognizes the difficulty of distinguishing between an illocutionary act and a perlocutionary act. The philosopher admits that performing an act necessarily entails performing a locutionary act. Austin draws attention, however, to the fact that an illocutionary act is not the consequence of a locutionary act. An illocutionary act is performed correctly if it is going to produce a particular effect. This does not mean that an illocutionary act is tantamount to the production of an effect. The only act that produces consequences is the perlocutionary act (2005, p. 112).

\footnotetext{
${ }^{3}$ In Monte Michèle's terms (2007).
} 
Postmodern poetic texts propose a variety of combinatorial formulas in which speech acts contribute to the perlocutionary configuration of the writerly act. The text of Mariana Marin's The Poem. At the Age of 13 camouflages inside the writerly gesture the illocutionary force of the poem and its perlocutionary sequel. The locutionary act is materialized in the textual matrix. The deictic references ("now", "13 years") orientate the reception of the writerly gesture at the level of the discourse. The forewarning act ("I shall now write the poem") achieves the perlocutionary goal (object) of alerting ("will confuse the audience"). It also has the perlocutionary consequence (sequel) ${ }^{4}$ of frightening ("if necessary it will trample them underfoot"). The actual epistemic modality ${ }^{5}$ establishes cognitive judgment, in a perlocutionary attempt to impose the argument ("Because really, Mr. Brecht"). The unquestionable performative ${ }^{6}$ of the verb that instantiates the world ("inventing") determines by way of the illocutionary force the assumption of the Adamic gesture of naming, in the discursive universe ("wanting to have a girlfriend / and then inventing her / in the form a diary / and naming her Kitty / (...) / and Bergen-Belsen at the age of 15"). The argument may not achieve its envisaged object, but as Austin emphasizes, it may have the perlocutionary sequel of persuading the interlocutor that the argument is true (2005, p. 114). The dissimilar end of the poem establishes, through the rhetic act, ${ }^{7}$ the authority of an impersonal entity:

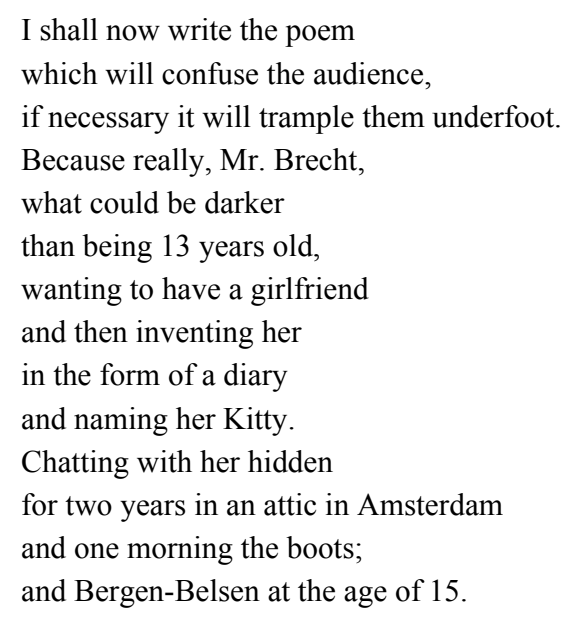

And then, history also says, peace broke out in the world! (Marin, The Poem. At the Age of 13, 1986, p. 20)

\section{Words and Things}

In the last century, John Langshaw Austin imposed a new perspective on language through speech acts theory, of fundamental importance for pragmatic linguistics. In the study How to Do Things With Words (1962, 2005), J. L. Austin addressed the distinction between constative and performative utterances and outlined two important aspects. On the one hand, locutionary aspects are highlighted in a constative utterance, to the detriment of illocutionary aspects. The philosopher points out that he uses "an over-simplified notion of correspondence with the facts". This over-simplification stems from the fact that the illocutionary aspect is involved at the level of

\footnotetext{
${ }^{4}$ In Austin's terms (2005, p. 114).

5 According to the classification proposed by Rodica Zafiu (2005, p. 678).

${ }_{7}^{6}$ In his analysis of performatives, Austin does not consider that the grammatical criterion is absolute (2005, p. 67).

${ }^{7}$ In Austin's terms (ibidem, p. 96).
} 
this correspondence. On the other hand, in a performative utterance greater attention is given to the illocutionary force of the statement than to the "dimension of correspondence with facts" (Austin, 2005, p. 135). These observations underscore the idea of identifying the "locutionary aspect" with the "dimension of correspondence with facts". In this respect, the locutionary aspect of an utterance is something by virtue of which the utterance represents reality, the accuracy of the representation being questioned (Récanati, 1980, p. 194).

The "dimension of correspondence with facts" was resumed by Austin in articles $(1950,1954)$ in which he polemically debated with Strawson the notion of "truth". Discussing this polemic, Récanati insists on aspects that outline a semantic theory. Depending on the relationship between the word and the world, Austin (1950) establishes two groups of conventions: descriptive and demonstrative. In the former category, words are correlated with "types of situations, of things, of events" existing in the world. In the latter category, words are correlated with historical situations that may be encountered in the world (apud Récanati, 1980, p. 194). The two categories of conventions, Récanati shows, determine the rapport between words and things. The meaning of words derives from the way in which words are correlated with things through the above-mentioned conventions. Discussing the locutionary aspect of an utterance, Austin surprisingly provides an ambiguous definition. It is defined both as a dimension of meaning and as a dimension of correspondence with things. Pointing out this contradiction, Récanati finds a balance between the two positions, advancing the hypothesis that what Austin understands through the locutionary meaning of an utterance is a part of the meaning that determines the descriptive and demonstrative conventions (1980, p. 195).

\section{The Pragmatic Functioning of phemes in Postmodern Poetic Texts}

In addressing the locutionary act, John Austin operates with a tripartite classification: the phonetic act, the phatic act, and the rhetic act. While a pheme is a unit of language, a rheme is a unit of speech. A pheme is nonsense. A rheme is vague, void, or obscure (2005, p. 98). John Austin believes that "saying" something means performing both locutionary and illocutionary acts. Phemes are an exception to this rule. ${ }^{8}$ This fact has not gone unnoticed in specialized studies. Récanati explains Austin's reserve towards these language units by showing that they exclude referential expressions whose reference "could then be determined by the rhetic act" (Récanati, 1980, p. 193). The criterion considered by Austin is the correspondence with the facts/things. The meaning of phemes is neither descriptive nor referential, but pragmatic. ${ }^{9}$ Accordingly, words are associated with the illocutionary act they perform.

Postmodern poetic texts exacerbate the pragmatic potential of phemes. In Florin Iaru's text On Sunday ${ }^{10}$ the speaking I launches, through the utterance gesture, the simulacrum of otherness. Adversative sequences prefigure alienation ("Let me speak about forgetting. But someone else has forgotten. / Let me speak about dying. But only the soul has died / Let me speak about ending. But only beginnings come to an end"). The occurrences of the pheme ("Ouch!") establish prospective pragmatic relations. ${ }^{11}$ The utterance is marked by illocutionary force. The absence of a determined meaning explains the impossibility of an association with a "state of affairs" through the

\footnotetext{
8 The terms Austin makes reference to are "damn" and "ouch" (2005, p. 125).

9 Récanati underlines that the sense of phemes does not derive from meaning (1980, p. 196).

${ }^{10}$ Florin Iaru's text was published under the title Duminica insalubră (Unwholesome Sunday) in Antologia poeziei generației 80 (Mușina, 2002, pp. 165-166).

${ }_{11}$ Croitor Balaciu considers that interjections may enter two types of semantic and pragmatic relations in an utterance: retrospective and prospective $(2005$, p. 665$)$.
} 
descriptive and demonstrative conventions of language (Récanati, 1980, p. 195). The illocutionary act performed thus warns of the danger of alienation. Reified otherness restricts communication to "Sunday objects". The effort of finding oneself through speech ("And still, let me speak about speaking") is derailed into the coarse affirmation of otherness:

Let me speak about forgetting. But someone else has forgotten.

Let me speak about dying. But only the soul has died.

Let me speak about ending. But only beginnings come to an end.

Ouch! My bed complains_-what

prehistoric animal has collapsed upon me!

Ouch! The mirror screams - stop

waking me from my sleep with your twaddle!

Ouch! I also cry out - underwear

solitude sentimental rag!

And still, let me speak about speaking. But someone else

overtakes me, fluttering like a giraffe,

"I! I said it first!"

"I! I loved it first!"

"We", Sunday objects cheer me on,

"we forgot it before you!" (...) (Iaru, On Sunday, 1984, p. 102)

The lexical mobility of the Romanian language has led to the proliferation of many versions for certain interjections. In the category of the aforementioned pheme, postmodern texts may feature several pragmatic realizations. In the poem Evoe!, Liviu Ioan Stoiciu discontinues the rhetic act ${ }^{12}$ through the insertion of a variant of the pheme "phew!" (“ă-lei!”). The illocutionary force allows the completion of the illocutionary act of stupefaction, caution. The performance of the rhetic act requires that a descriptive or a referential meaning should be associated with the pheme. In exceptional cases, as Récanati states (1980, p. 195), Austin overlooks the rigorousness of the rule, considering it sufficient if just one of the meanings is assigned. The variations of the pheme "ugh!" ("aoleu!") do not alter the initial status, regardless of the aforementioned occurrences in Liviu Ioan Stoiciu's discourse. Their utterance does not refer to a given historical situation, nor does it describe a situation:

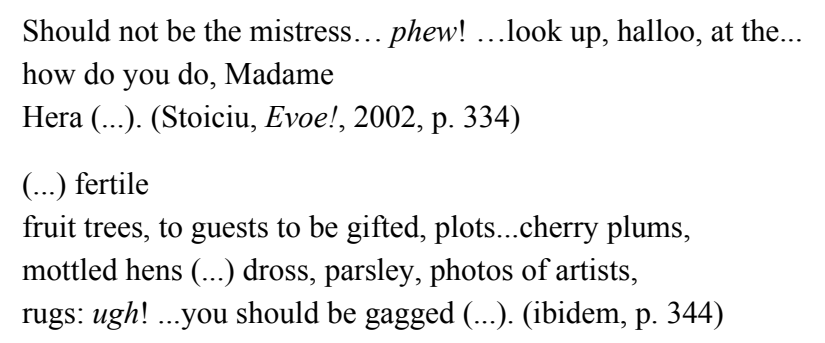

The uncommon variant of the pheme proposed by Marin Mincu in Stork Hunters does not alter the pragmatic situation:

25. what happens to the storks

a weak rumour broke through above the houses

the little ones seemed excited

with the show, went up into the nests

${ }^{12}$ In Austin's terms (2005). 
throwing eggs and down feathers at one another

Phew-ew-eee I climbed up a tree

and what can you see from there

what can the stork see when it

sits with its eyes closed. (Mincu, Stork Hunters, 1980, p. 56)

Among the pragmatic strategies encountered in postmodern texts, we may notice a tendency to associate the pheme ("ah!") with a referential meaning in Florin Iaru's poem A Rainy Day on Peace Street. The echoing question is not simply a reiterated question. ${ }^{13}$ The structure may be a mark of incomprehension or confusion. Moreover, the interrogative occurrence transposes the pheme into metalanguage. However, instead of assigning a descriptive or referential meaning to the pheme, the discursive strategy interrupts the interlocutory relation. In this context, the performance of the illocutionary act is successfully accomplished through the perlocutionary effect. The order brings about fear:

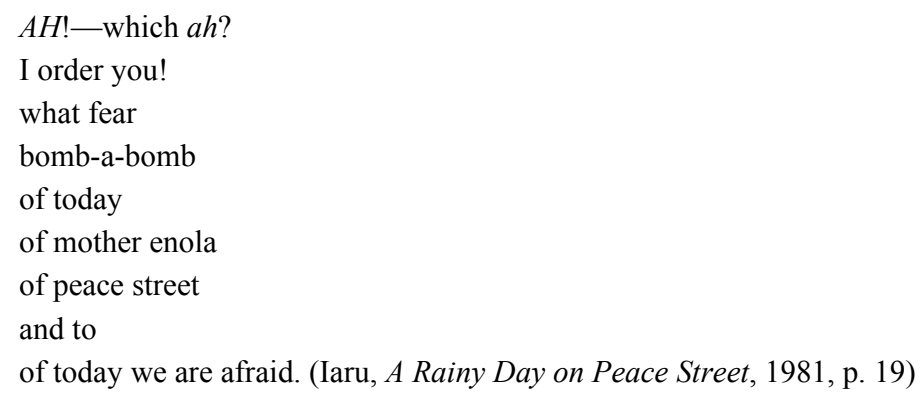

Contextually, in Florin Iaru's poem Delayed Strike, the prepositional group creates the impression that the pheme has a referent. Stylistically, the word-thing relation is metaphorically projected into the object-oriented dimension ("words"- "knitting needles"). In the relationship between words and things, "sense and reference (naming and referring)" are "ancillary acts performed in performing the rhetic act" (Austin, 2005, p. 97). It has been noted that, for Austin, "to name" means "to assign a particular name to a particular type of object" (Récanati, 1980, p. 195). The use of the grammatical instrument ("without") does not imply the assignation of a determined meaning to the "ambiguous constituent" of the pheme ("ah!").

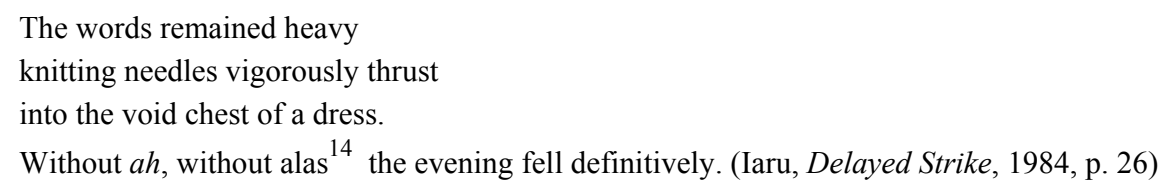

Not even the phenomenon of coalescence can grant descriptive-referential meaning to a pheme. In Florin Iaru's text In the Small Gazebo, the reiteration of the pheme ("WOOHOO!") emphasizes the illocutionary force of the utterance. The illocutionary act marks the existence of imminent danger. The stylistic value of the gerund is compounded by echoing repetition of the pheme. Through coalescence, the determined meaning is not assimilated by the "ambiguous constituent" of pheme; on the contrary, we may notice a transfer of illocutionary force in the established pragma-semantic relation. The terrifying atmosphere and the lack of bearings are

\footnotetext{
13 In the terms of Francis Jacques (1985, p. 277).

14 The interjection vai (alas) was included by Mariana Țuțescu in the category of epistemic modalizers, of an enunciatory-evaluative, elocutionary, axiological, and interactive nature (2006, p. 37).
} 
maintained by means of assonance. The perlocutionary effect at the utterance level is also felt at the uttered level. The parenthetical insertion constitutes a counterpoint in the created textual worlds. The merger between textual code - social code parodically reinforces the perlocutionary effect of guilt. The communication simulacrum transposes the relation ipseity - youity ${ }^{15}$ into the impersonal register of culpable address:

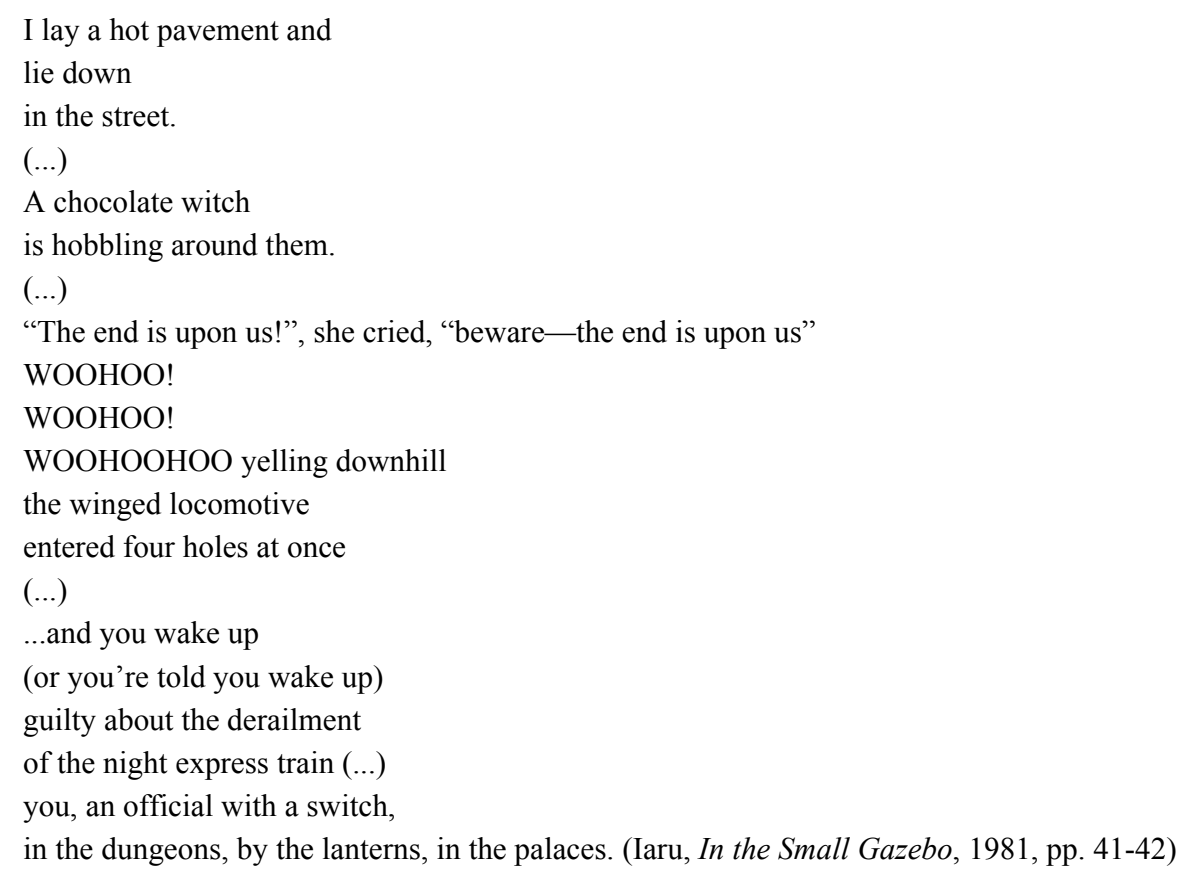

Phemes are denied the locutionary aspect because they do not correspond to any fact or situation, "ne réfèrent à rien et n'ont pas de contenu représentatif' (Récanati, 1980, p. 194).

\section{The Fit Between Words and the World}

In the study entitled Expression and Meaning (1979) (Sens et expression 1982), John Searle undertakes a classification of illocutionary acts based on 12 criteria. The second criterion refers to différence de direction d'ajustement entre les mots et le monde (1982, p. 41). According to this criterion, in some illocutions words (their propositional content) tally with the world, while in the other illocutions the world tallies with words. The first category includes assertions, descriptions, and explanations; the second category includes promises, questions, orders, and oaths. What Searle understands through the "difference in direction of fit" is the relation between the world and the propositional content. This direction of fit is a "consequence of illocutionary point" (Searle, 1982, pp. 41-42).

In Alexandru Muşina's text Avant-propos, we may note the attempt of getting the words to match the world/things. The alternation negation-affirmation leads to an approximation of the poem's "being", perceived as a prey by the "relentless" beasts that are chasing it down. The poem does not exist, it has no being ("For it, the poem, does not exist"). The relation between the word and the world is generated by the substitution of the writerly-gestural codes. The illocutionary force maintains the relation if the juxtaposed semiotic systems word/utterance - gesture/act (Berrendonner, 1981, p. 85). The imaginary hunt takes place in the textual space.

${ }^{15}$ In the terms proposed by Eduard Pamfil and Doru Ogodescu (1976). 
The hunting act assigns the poem representations pertaining to the animal regnum ("hippopotamus"), to the sphere of Christian spirituality ("phthisic bird, from paradise") and the mythological realm ("unicorn", "gryphon"). Metonymically, the writerly object ("ink") chases the chimera of the poem, textually accomplished after the likeness of the world ("When the ink is thick, we'll catch / A clumsy hippopotamus"). The poem borrows symbolic semblances for instinctual mundane knowledge, divine spiritual knowledge, and mythological knowledge. The fit between words and the world or, by extension, between the propositional content and the mode of knowledge is the sequel of the illocutionary object of configuring the poem into being. Since the poem is non-existent, its archetype is approximated, each time, with a different semblance. The speaking I, symbolically transposed into a cynegetic collectivity ("We're chasing it with beautiful flags, / With silver bells and ardent feelings"), projects the action of chasing the poem-prey ("unicorn", "gryphon") into mythological timelessness. Moreover, in this mythological register, the ambiguity of getting the propositional content to match the world derives from the intension and extension of the terms unicorn and gryphon. Logically speaking, they are absolute, concrete, positive, simple, void, general, and distributive terns. Similarly, the prototypal configuration poem-bird from paradise remains anchored in the register of Christian spirituality, the intension and extension of the term substantiating the rapport of ambiguity between the propositional content and the world/things. The illocutionary object of configuring the being of the poem, through the cynegetic act, imposes, through the perlocutionary effect, a triadic model of knowledge:

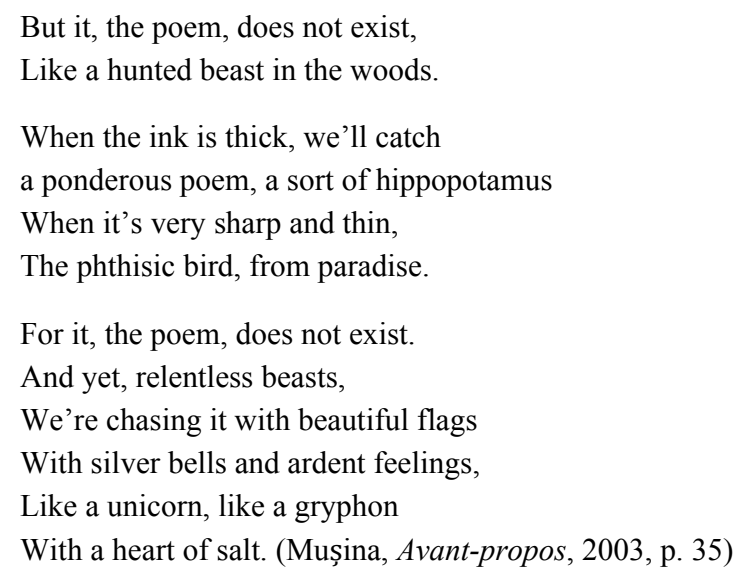

The approach of postmodern poetic texts from the perspective of the concepts developed by John Austin and John Searle brings further pragmatic insights into the theory of speech acts. Thus, the pragmatic meaning of phemes prevails over descriptive-referential meaning. Last but not least, the criterion of "difference in direction of fit" valorizes pragmatically the illocutionary force of the utterance.

\section{Conclusion}

The theory of speech acts, developed by John Langshaw Austin, has changed the perspective on language. Its importance to pragmatic linguistics has been widely recognized. The specific conventions of literary discourse confer it a pragmatic dimension.

Romanian postmodern poetry fully exploits the valences of speech acts. In Matei Vişniec's poem, the descriptive strategies do not exclude the dramatization of the ensemble of actions. We may notice, in 
deconstructing the poem, the conversational simulacrum, which is a sign of the alienation and negotiation of meaning. In Mariana Marin's text, the writerly gesture focuses attention on the combinatorial possibilities of speech acts. The illocutionary/perlocutionary game reinforces the persuasive approach.

The attention given to the constative-performative distinction privileges, on the one hand, locutionary over illocutionary aspects and, on the other hand, the illocutionary force of the utterance over the dimension of correspondence with facts.

In understanding the locutionary aspect of utterances, Austin supported a contradictory point of view, which Récanati has reconciled by highlighting the dependence of the locutionary meaning of an utterance upon descriptive and demonstrative conventions.

The dichotomy pheme-rheme is based on the criterion of correspondence with facts. From this perspective, the meaning of phemes is pragmatic. This feature is capitalized upon in postmodern poetic texts. Thus, prospective pragmatic relations may be established in Florin Iaru's poetry through them. We may also note, in the case of the same author, a tendency to assign a referential meaning to phemes. Sometimes, in the poetry of Liviu Ioan Stoiciu and Marin Mincu, the occurrences of a pheme do not necessarily entail amending their initial status. The pragma-semantic relation may institute, in Florin Iaru's text, a transfer of illocutionary force through coalescence.

John Searle resumed several strategic points of Austin's theory of speech acts and rethought the taxonomy of illocutionary acts. The "difference in direction of fit" brings into focus the relationship between the world and the propositional content. In postmodern texts, getting words to match the world is a source of poeticity. The gliding of the writerly-gestural codes generates the rapport between the word and the world. In Alexandru Muşina's text, the configuration of the poem's being - the fit between the propositional content and the mode of knowledge — represents a sequel of the illocutionary object.

\section{References}

Adam, J. M., \& Petitjean, A. (2007). Textul descriptiv (Descriptive text). (C. Strătilă, Trans.). Iași: Institutul European.

Austin, J. L. (1962/2005). Cum să faci lucruri cu vorbe (How to do things with words). (S. Corneanu, Trans.). Pitești: Paralela 45.

Berrendonner, A. (1981). Éléments de pragmatique linguistique (Elements of pragmatic linguistics). Paris: Les Éditions de Minuit. Croitor Balaciu, B. (2005). Interjecția. Gramatica limbii române (Interjection, Romanian language grammar) (Vol. I, pp. 657-685).

V. G. Romalo (Ed.). București: Editura Academiei Române.

Iaru, F. (1981). Cântece de trecut strada (Street crossing songs). București: Albatros.

Iaru, F. (1984). La cea mai înaltă ficțiune (At the highest fiction). București: Cartea Românească.

Iser, W. (1978/2006). Actul lecturii. O teorie a efectului estetic (The act of reading. A theory of the aesthetic effect). Pitești: Paralela 45.

Jacques, Fr. (1985). L'espace logique de l'interlocution. Dialogiques II (The logic conversation space). Paris: Presses Universitaires de France.

Marin, M. (1986). Aripa secretă (Secret wing). București: Cartea Românească.

Mincu, M. (1980). Pradă realului (Surrender to reality). București: Cartea Românească.

Monte, M. (2007). Poésie et effacement énonciatif (Poetry and ennunciative deletion). Semen [En ligne], 24. Retrieved from http://semn.revues.org./6113

Mușina, Al. (2002). Antologia poeziei generației '80 (Anthology of the 80s generation poetry) (2nd ed.). Brașov: AULA.

Mușina, Al. (2003). Poeme alese (1975-2000) (Selected poems 1975-2000). Brașov: AULA.

Pamfil, E., \& Ogodescu, D. (1976). Persoană și devenire (Person and becoming). București: Editura Științifică și Enciclopedică.

Récanati, Fr. (1980). Qu'est-ce qu'un acte locutionnaire? (What is a locutionary act?) Communication, 32, $190-215$. doi:103406/comm.1980.1485 
Searle, J. R. (1979/1982). Sens et expression. Études de théorie des actes de langage (Expression and meaning. Theoretical studies of speech acts). Traduction par Joëlle Proust. Paris: Les Éditions de Minuit.

Stoiciu, L. I. (2002). Evoe!, in Alexandru Mușina. Antologia poeziei generației '80 (Evoe! in Alexandru Mușina. Anthology of the 80s Generation Poetry) (2nd ed., pp. 232-247). Brașov: AULA.

Țuțescu, M. (2006). L'interjection - modalisation, axiologisation et grammaticalisation. Le cas des interjection roumaines zău et vai (Interjection - modalization. axiologization and grammaticalization. The case of the Romanian interjections zău and vai). Langages, 161, 37-46. doi:10.3406/lgge.2006.2703

Vișniec, M. (2004). Orașul cu un singur locuitor (antologie de poezie 1980-2004) (The town with one inhabitant (Poetry anthology 1980-2004)). Pitești-București: Paralela 45.

Zafiu, R. (2005). Modalizarea. Gramatica limbii române (Modalization. Romanian language grammar) (Vol. II, pp. 673-697). V. G. Romalo (Ed.). București: Editura Academiei Române. 